\title{
SISTEM INFORMASI SIMPAN PINJAM BADAN KESWADAYAAN MASYARAKAT STUDI KASUS BKM SARANA MAKMUR
}

\author{
Nanik Susanti \\ Dosen Fakultas Teknik, Program Studi Sistem Informasi \\ Universitas Muria Kudus \\ Email: naniksusanti26@gmail
}

\begin{abstract}
ABSTRAK
Badan Keswadayaan Masyarakat sebagai produk P2KP yang diprogramkan oleh pemerintah bertujuan untuk menanggulangi kemiskinan di pedesaan. Salah satu kegiatan BKM adalah penyedia layanan jasa simpan pinjam bagi masyarakat dalam kelompok KSM. Untuk memberikan pelayanan yang lebih baik pada penelitian ini akan dirancang sisteminformasi simpan pinjam. Tujuan penelitian ini adalah menghasilkan sistem informasi simpan pinjam yang berbasis komputer yang dapat membantu bagian Unit Pengelola Keuangan dalam memproses data simpan pinjam menjadi lebih mudah, cepat dan tepat. Sistem informasi simpan pinjam ini memuat informasi data KSM, data pinjaman, data simpanan dan data angsuran yang terhubung dengan data pinjaman. Pembuatan Aplikasi simpan pinjam dilakukan dengan menggunakan software visual borland delphi 7.0
\end{abstract}

Kata kunci: Sistem informasi, simpan pinjam, BKM

\begin{abstract}
Badan Keswadayaan Masyarakat as a product P2KP programmed by the government aims to reduce poverty in rural areas. One of the activities BKM is service providers in the community savings and loans for KSM. In order to provide better service in this study will be designed sisteminformasi savings and loans. The purpose of this research is to produce a saving and loan information systems computer-based can help section in the Financial Management Unit to process savings and loans became easier, faster and precise. Savings and loan information system contains data information KSM, loan data, saving data and pay installment data connected with loan data. Making savings and loan applications done using Borland Delphi 7.0 visual software
\end{abstract}

Keywords: information systems, savings and loans, BKM

\section{PENDAHULUAN}

Badan Keswadayaan Masyarakat yang disingkat BKM[1] merupakan suatu lembaga keuangan yang dibentuk dari masyarakat desa sebagai organisasi sejenis perbankan yang di miliki oleh masyarakat desa yang menyediakan pelayanan jasa perkreditan bagi masyarakat diwilayahnya. BKM sendiri merupakan program pemerintah yang digunakan sebagai perencanaan penaggulangan kemiskinan pada pedesaan (P2KP). Permodalan BKM sendiri berasal dari bantuan Bank Dunia. Dan pengelolaan BKM sekarang dibawah pengawasan Bappeda

Tujuan didirikan BKM Sarana Makmur adalah untuk membantu masyarakat diwilayah desa terutama masyarakat kecil sesuai dengan program pemerintah dalam rangka mengentaskan kemiskinan. Bantuan yang diberikan adalah dalam bentuk permodalan yang berupa kredit simpan pinjam yang dapat diperoleh dengan cara yang mudah, murah dan cepat.

Pemberian pelayanan kepada KSM (Kelompok Swadaya Masyarakat) yang mudah, murah dan cepat perlu dilakukan sistem informasi pengolahan data yang baik, tepat dan akurat, agar segala informasi mengenai data simpan pinjam KSM yang dibutuhkan oleh bagian-bagian yang terkait dapat diperoleh dengan cepat, lengkap dan tepat.

Dengan sistem informasi yang terkelola dengan baik maka memungkinkan membuat keputusan-keputusan yang efektif dan tepat waktu dalam menjalankan fungsi-fungsi perencanaan, pengarahan dan pengontrolan aktifitasaktifitas yang menjadi tanggung jawab mereka.

Di BKM Sarana Makmur sendiri dalam pengolahan data simpan pinjam masih menggunakan cara manual, sehingga untuk memperoleh data-data yang cepat mengenai laporan KSM pinjam, KSM simpan masih kesulitan dalam pendataannya, karena jumlah KSM di BKM Sarana Makmur sekarang sudah cukup banyak. Sedang 
tersedianya komputer yang ada di BKM Sarana Makmur masih belum optimal penggunaanya, karena hanya digunakan untuk administrasi surat menyurat.

\section{LANDASAN TEORI}

\subsection{Sistem Informasi}

Menurut [2] Sistem informasi adalah suatu sistem di dalam suatu organisasi yang mempertemukan kebutuhan pengolahan transaksi harian, mendukung operasi, bersifat manajerial dan kegiatan strategi dari suatu organisasi dan menyediakan pihak luar tertentu dengan laporan-laporan yang diperlukan.

\subsection{Konsep Dasar Simpan Pinjam}

Simpan pinjam teriri dari 2 kata[3] yaitu "simpan" dan "pinjam" dan terdiri 2 transaksi yaitu transaksi simpan dan transaksi pinjam. Simpanan adalah suatu kepercayaan seseorang untuk menyimpan uang pada suatu tempat tertentu. Macam-macam simpanan dibedakan menjadi 2 tabungan dan deposito berjangka.

Tabungan adalah simpanan rupiah dan valuta asing milik pihak ketiga pada bank yang bersangkutan termasuk kantornya di luar negeri, yang penarikannya dapat dilakukan menurut syarat-syarat dan cara-cara tertentu. Dalam pengertian termasuk simpanan yang pengambilannya harus diberitahukan beberapa hari sebelumnya dan penarikannya hanya dapat dilakukan dengan buku tebungan dalam valuta asing dimasukkan ke kolom valuta asing.

Deposito berjangka adalah deposito berjangka, deposito on call, sertifikat deposito dan deposito lainya yang diterima oleh bank termasuk kantornya di luar negeri, baik dalam rupiah maupun valuta asing milik pihak ketiga termasuk bank lain yang penarikannya dapat dilakukan jangka waktu tertentu sesuai dengan perjanjian antar bank yang bersangkutan dengan penyimpanan. Deposito dalam rupiah dan deposito dalam valuta asing dimasukkan ke dalam kolom valuta asing.

Kredit berasal dari bahasa latin "credere" atau "credo" yang berarti "percaya". Kredit adalah penyerahan suatu nilai berdasarkan kepercayaan untuk dikembalikan pada masa yang akan datang. Pada dasarnya kredit tergantung pada 3 hal yaitu :

a. Bahwa posisi materi dari peminjam mampu untuk mengembalikan modal yang dipinjam.

b. Kepercayaan bahwa peminjam akan mengembalikan hutangnya.

c. Kepercayaan bahwa hokum-hukum yang sah dapat melindungi semua pihak yang terlibat dalam transaksi kredit tanpa ada pihak yang dirugikan.

Dalam pelaksanaan perbankan, dalam pemberian kredit kepada nasabah maka tidak lepas dari analisa pemberian kredit. Adapun kriteria-kriteria pemberian kredit tersebut adalah :

a. Character (watak)

Tujuan untuk mengetahui watak, sifat-sifat yang positif pada pengurus perusahaan yang nantinya akan tercermin dalam kemauan dan tanggung jawabnya.

b. Capacity (kemampuan)

Tujuan untuk mengetahui kemampuan calon debitur dalam melunasi kewajiban-kewajibannya dari hasil usaha yang dilakukan atau yang akan dilakukan, kaitanya dengan kegiatan yang akan dibiayai oleh BKM.

c. Capital (modal)

Tujuan untuk mengetahui seberapa besar modal yang dimiliki oleh calon nasabah dibandingkan dengan jumlah kredit yang akan diminta.

d. Collateral (jaminan)

Tujuan untuk mnegetahui seberapa besar jaminan yang akan diberikan dibandingkan dengan jumlah kredit yang diterimanya.

e. Condition of Economy (kondisi perekonomian)

Tujuan untuk mengetahui sejauh mana pengaruh kondisi perekonomian yang ada (politik, ekonomi, sosial dan budaya) terhadap produk yang dihasilkan oleh nasabah.

f. Constraint (hambatan)

Tujuan untuk mengetahui hambatan-hambatan yang terjadi pada usaha nasabah dalam melakukan binisnya di suatu tempat.

Fungsi kredit dalam perekonomian secara garis besar adalah sebagai berikut :

1. Kredit dapat meningkatkan daya guna modal/uang.

2. Kredit dapat meningkatkan daya guna suatu barang.

3. Kredit dapat meningkatkan peredaran dan lalu lintas uang. 
4. Kredit dapat menimbulkan semangat berusaha masyarakat.

5. Kredit sebagai alat stabilitas ekonomi.

6. Kredit sebagai alat hubungan ekonomi internasional.

7. Kredit sebagai jembatan untuk meningkatkan pendapatan nasional.

Sementara kredit dapat dibedakan berdasarkan :

1. Hasil pemakaiannya

a. Kredit positif atau produktif, pemakaian kredit menghasilkan sebesar jumlah pinjaman ditambah dengan bunga, biaya pinjaman lainnya dan keuntungan untuk dirinya.

b. Kredit netral, pemakaian kredit sebesar jumlah pinjaman ditambah bunga dan biaya pinjaman lainnya.

c. Kredit negatif atau tidak produktif, hasilnya yang diperoleh dari pemakai kredit kurang dari jumlah pinjaman , bunga dan pinjaman lainnya.

2. Sifat pengguanaannya

a. Kredit konsumtif, dipergunakan peminjam untuk kepentingan konsumsi yang memenuhi kebutuhan hidupnya saja.

b. Kredit produktif, ditujukan untuk produksi dalam arti luas.

3. Keperluan kredit

a. Kredit produksi/eksploitasi, diperlukan untuk meningkatkan produksi, baik secara kualitatif dan kuantitatif.

b. Kredit perdagangan, dipergunakan untuk meningkatkan kegunaan tempat suatu barang.

c. Kredit investasi, dipergunakan untuk investasi yaitu untuk perbaikan atau menambah modal beserta fasilitas-fasilitas lain yang berhubungan dengan hal tersebut.

Jangka waktu kredit dibedakan menjadi :

a. Kredit jangka pendek, pemakaian kredit kurang dari satu tahun.

b. Kredit jangka menengah, pemakaian kredit antara 1 sampai 5 tahun.

c. Kredit jangka panjang, pemakaian kredit lebih dari lima tahun.

Menurut [4] cara perhitungan bunga yang dibebankan pada pokok pinjaman adalah sebagai berikut:

d. Sliding Rate

Adalah pembebanan bunga terhadap nilai pokok pinjaman akan semakin menurun dari bulan ke bulan / setiap periode akibat adanya pelunasan.

Contoh :

Pokok pinjaman : : Rp. 200.000,00

Bunga $\quad: 2 \%$ per bulan

Jangka waktu : 10 bulan

Angsuran pokok $\quad$ : Rp. $200.000,00 / 10$ bulan $=$ Rp. $20.000,00$

Bunga : Rp. $200.000,00 \times 0,2 \quad=$ Rp. $4.000,00$

Angsuran I = Rp. 20.000,00 + Rp. 4.000,00 = Rp. 24.000,00

Dengan metode perhitungan Sliding Rate maka besarnya bunga berubah berdasarkan saldo pinjaman tiap periodenya.

e. Flate Rate

Adalah pembebanan bunga terhadap pokok pinjaman akan tetap. Baik bunga maupun jumlah angsuran pokok dari periode ke periode lainya.

Contoh :

Pokok pinjaman : : Rp. 200.000,00

Bunga $\quad: 2 \%$ per bulan

Jangka waktu : 10 bulan

Angsuran pokok : Rp. 200.000,00/10 bulan = Rp. $20.000,00$

Bunga $\quad$ : Rp. $200.000,00 \times 0,2 \quad=$ Rp. $4.000,00$

Angsuran/bulan = Rp. 20.000,00+Rp. 4.000,00 = Rp. 24.000,00

Angsuran tiap bulan atau tiap periode jumlahnya tetap.

Dalam suatu perkreditan ada 2 macam jaminan antara lain :

1. Kredit dengan jaminan

Tujuan untuk mencegah hal-hal yang tidak diinginkan (memperkecil resiko). Jaminan dapat berupa sertifikat rumah, tanah, kios maupun BPKB kendaraan.

2. Kredit tanpa jaminan

Dilaksanakan berdasarkan keputusan kebonafitan dan prospek usaha debitur yang bersangkutan. 


\section{TINJAUAN PUSTAKA}

Penelitian yang ditulis [5] dengan judul "Sistem Informasi Simpan Pinjam Koperasi Mitra Mandiri Jetak". Penelitian ini mengungkapkan permasalahan yaitu belum adanya sistem informasi simpan pinjam yang memadai untuk mewujudkan keakuratan, keamanan dan keselamatan data-data yang dimilikinya. Penelitian ini bertujuan untuk meningkatkan efisiensi kerja di Koperasi Simpan Pinjam Mitra Mandiri, khususnya bendahara agar lebih mudah dalam pencatatan transaksi-transaksi anggota koperasi serta memberikan laporan yang akurat dan tepat waktu.

Penelitian lain yang ditulis [6] dengan judul "Sistem Informasi Simpan Pinjam Ada Koperasi Wanita Putri Harapan Desa Jatigunung Kecamatan Tulakan" mengungkapkan sistem yang digunakan masih konvensional yaitu menggunakan buku dan Microsoft Excel. Cara ini kurang efektif karenatransaksi simpan pinjam yang terjadi semakin tinggi sehingga penghitungan juga semakin banyak. Tujuan dari penelitian ini adalah menghasilkan sistem informasi simpan pinjam yang dilengkapi pengolahan akuntansi dan Sisa Hasil Usaha (SHU). Dengan menggunakan sistem informasi, pengolahan data dan pembuatan laporan menjadi lebih mudah, cepat dengan data akurat.

\section{METODE PENELITIAN}

\subsection{Metode Pengembangan Sistem}

Metode yang digunakan dalam pembuatan perangkat lunak pada penelitian ini menggunakan model Waterfall Model. Fase-Fase dalam Waterfall Model, yaitu :

1. Analisis dan definisi persyaratan, Pelayanan, batasan dan tujuan sistem ditentukan melalui konsultasi dengan user sistem. Persyaratan ini kemudian didefinisikan secara rinci dan berfungsi sebagai spesifikasi sistem.

2. Perancangan sistem dan perangkat lunak, Proses perancangan sistem membagi persyaratan dalam sistem perangkat keras atau perangkat lunak. Kegiatan ini menentukan arsitektur sistem secara keseluruhan. Perancangan perangkat lunak melibatkan identifikasi dan depenelitian abstraksi sistem perangkat lunak yang mendasar dan hubungan-hubungannya.

3. Implementasi dan pengujian unit, Pada tahap ini, perancangan perangkat lunak direalisasikan sebagai serangkaian program atau unit program. Pengujian unit melibatkan verifikasi bahwa setiap unit telah memenuhi spesifikasinya.

4. Integrasi dan pengujian sistem, Unit program atau program individual diintegrasikan dan diuji sebagai sistem yang lengkap untuk menjamin bahwa persyaratan sistem telah terpenuhi.

5. Pengoperasian dan Perawatan, pada tahap ini, meliputi pengoperasian sistem dan pemeliharaannya.

\subsection{Metode Pengumpulan Data}

Metode pengumpulan data yang digunakan dalam penelitian ini adalah sebagai berikut:

1. Metode Observasi, pengamatan yang dilakukan secara sengaja dan sistematis mengenai gejala-gejala psikis untuk kemudian dilakukan pencatatan dengan menggunakan dan mempelajari praktek-praktek pelaksanaan di tempat penelitian meliputi Proses input data simpan pinjam KSM dan Pengolahan Data simpan pinjam KSM

2. Metode Kepustakaan, untuk memperluas cakrawala pandang, maka perlu membaca buku yang sesuai dengan permasalahan penulis, sebagai bahan pertimbangan untuk mendapatkan data sekunder yang mengacu pada literatur, buku, diktat, catatan yang dapat menunjang penyusunan penelitian ini.

3. Metode Wawancara, untuk mendapatkan masukan berkenaan dengan sistem informasi yang ada maka penulis menanyakan yang berkaitan dengan permasalahan tersebut dengan pihak Manajer UPK (Unit Pengelola Keuangan), Pegawai / Staf UPK.

4. Metode Dokumentasi, metode ini penulis gunakan untuk mengetahui proses-proses yang pernah dilakukan oleh Manajer UPK (Unit Pengelola Keuangan), Pegawai / Staf UPK.

\section{HASIL PENELITIAN DAN PEMBAHASAN}

\subsection{Evaluasi Sistem Lama}

BKM Sarana Makmur merupakan badan pelayanan kredit masyarakat yang dalam melaksanakan administrasi simpan pinjam masih menggunakan cara manual, sehingga sering dijumpai kendala-kendala yang 
bersifat manusiawi yang tidak bisa dihindarkan. Hal ini mengakibatkan kebutuhan informasi yang diperoleh kurang maksimal dan sering terjadi keterlambatan informasi.

Berdasarkan hasil survei terhadap aktivitas administrasi simpan pinjam pada BKM Sarana Makmur, maka masih banyak kendala yang dihadapi yang tidak dapat diselesaikan dengan sistem manual seperti :

1. Pencarian data pada bagian UPK yang ada belum dapat menghasilkan informasi yang cepat, tepat dan akurat serta sering kali memakan waktu.

2. Pada bagian UPK resiko kesalahan perhitungan sangat besar, karena masih menggunakan sistem manual sehingga bisa mengakibatkan kerugian keuangan.

\subsection{Perancangan Sistem Baru}

Dalam perancangan sistem baru ini adalah suatu cara bagaimana menempatkan data dalam file database sehingga data tersebut dapat diakses dengan baik dalam sistem yang akan digunakan. Dalam perancangan sistem baru ini diharapkan mampu meningkatkan efisiensi kerja dan kualitas pekerjaan yang lebih baik, serta dapat membantu dalam pengambilan keputusan untuk mengatasi masalah-masalah yang muncul.

Untuk perancangan model simpan pinjam pada BKM Sarana Makmur digambarkan dalam bentuk Context Diagram seperti pada gambar 1 sebagai berikut:

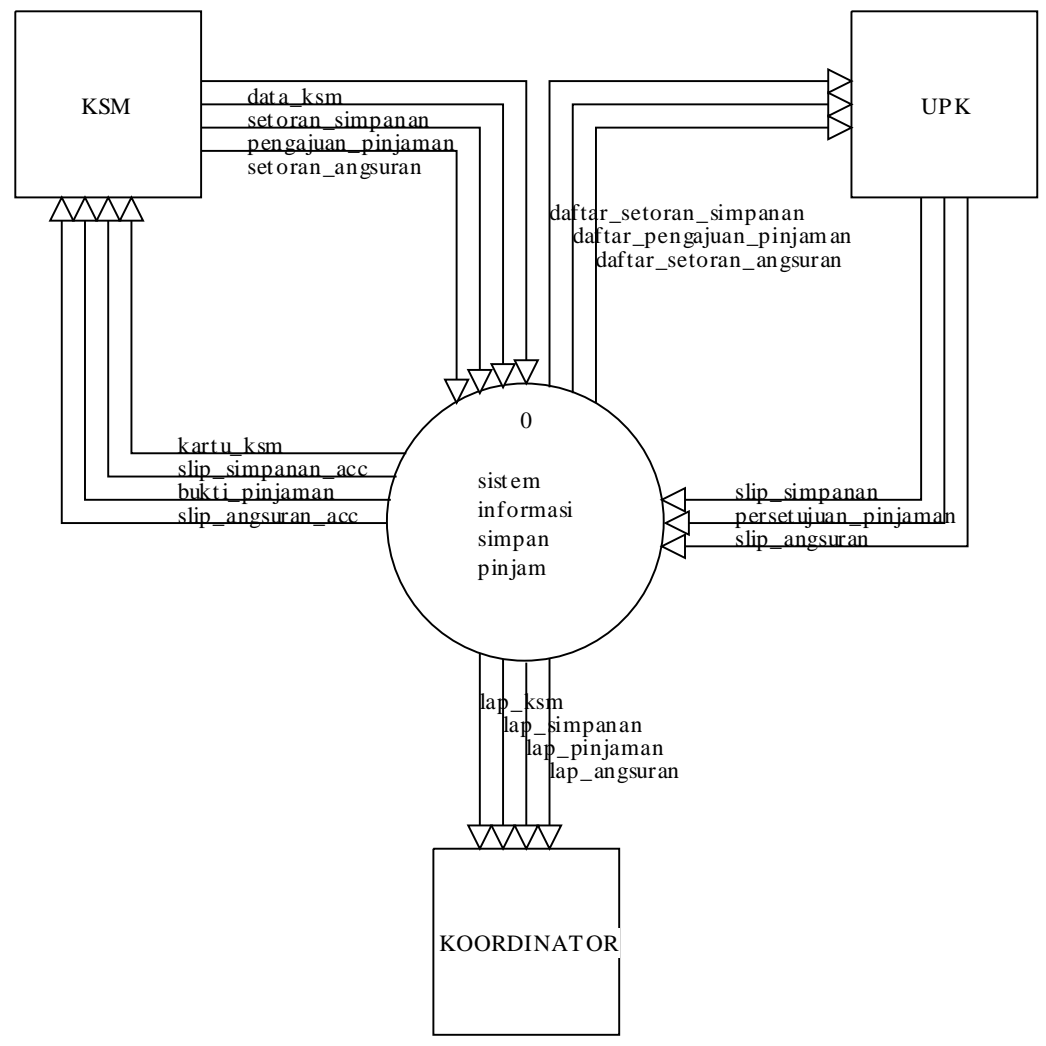

\section{Gambar 1. Context Diagram sistem informasi simpan pinjam BKM}

Context Diagram diatas menggambarkan diagram alir sistem pengolahan data simpan pinjam. Dari KSM yang menyerahkan data KSM dan form untuk pengajuan pinjaman ke sistem, kemudian memperoleh bukti pinjaman untuk melakukan peminjaman, buku tabungan untuk melakukan simpanan dan bukti angsuran untuk melakukan pengangsuran kepada UPK melalui sistem. Kemudian UPK melakukan proses pencatatan serta pembuatan laporan data KSM, laporan pinjaman, laporan simpanan, laporan pengembalian dan laporan pengangsuran yang diserahkan kepada pimpinan.

Dari Context Diagram diatas kemudian dijabarkan dalam DFD level 0 seperti yang terlihat pada gambar 2. 


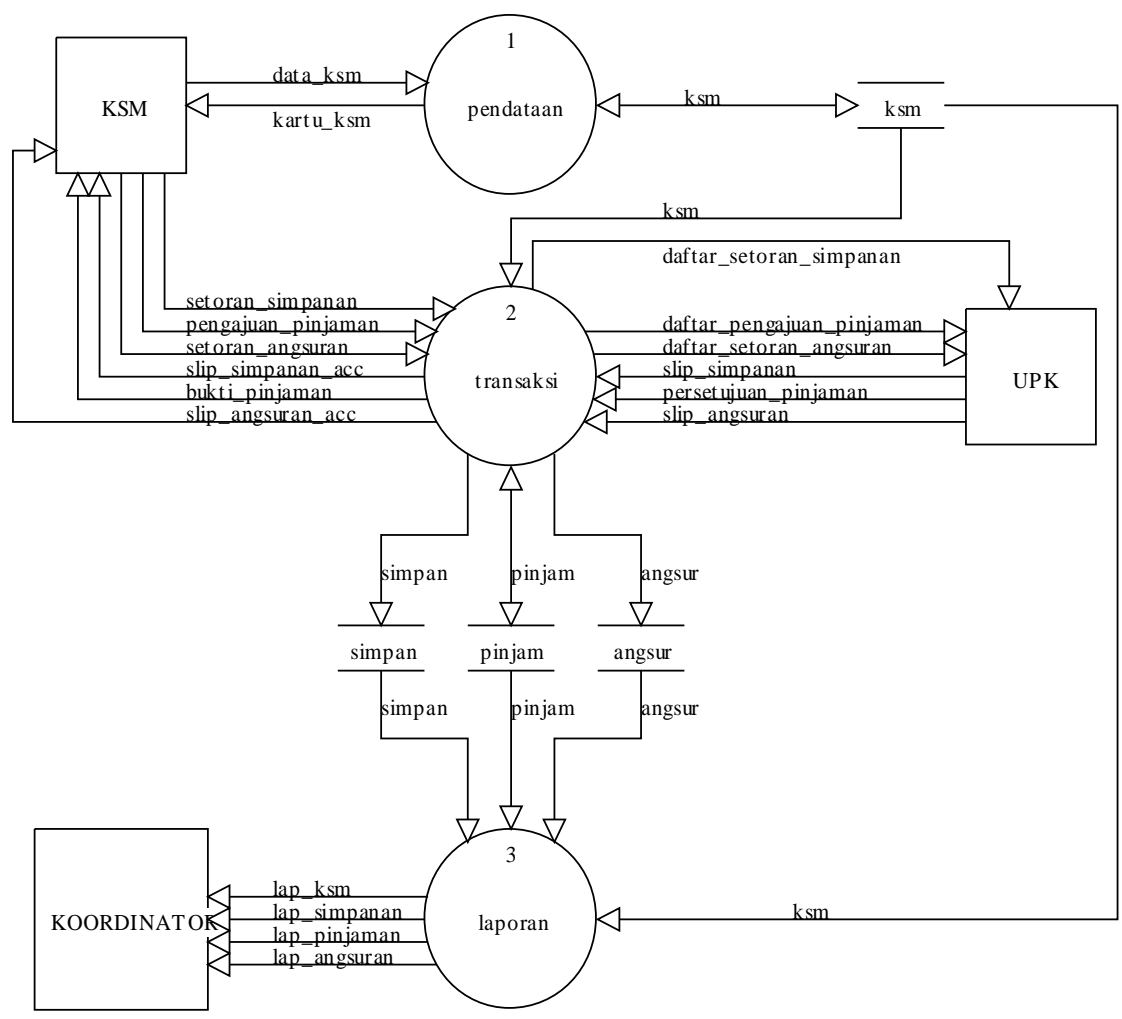

Gambar 2. DFD Level 0 sistem informasi simpan pinjam BKM

DFD Level 0 adalah penggambaran alir data serta proses - proses yang ada dalam context diagram yang kemudian dilakukan penyimpanan - penyimpanan dalam sebuah file.

\subsection{Perancangan Database}

Pada perancangan database digunakan untuk memperlihatkan relasi antar table di dalam sebuah database untuk penyimpanan data. Relasi antar tabel ditunjukan oleh gambar 3.

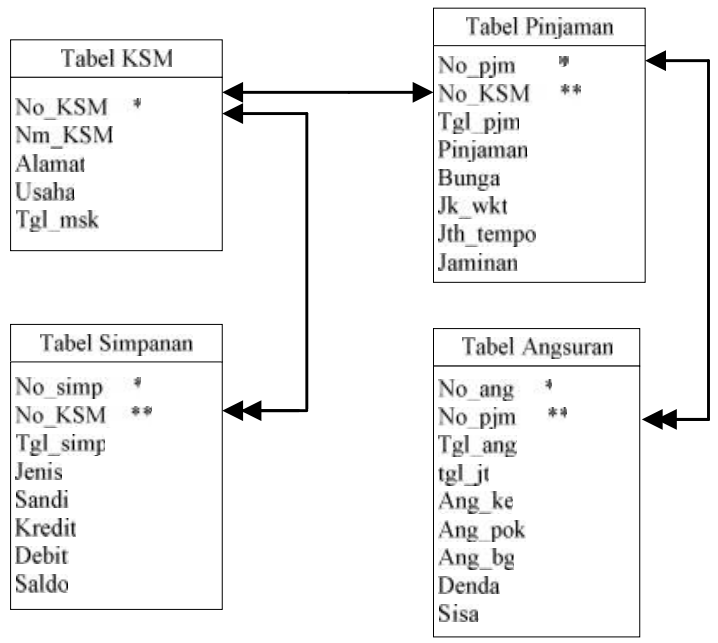

Gambar 3. Relasi tabel 


\subsection{Perancangan Interface}

Tampilan form pinjaman ditunjukkan pada gambar 4 berikut ini.

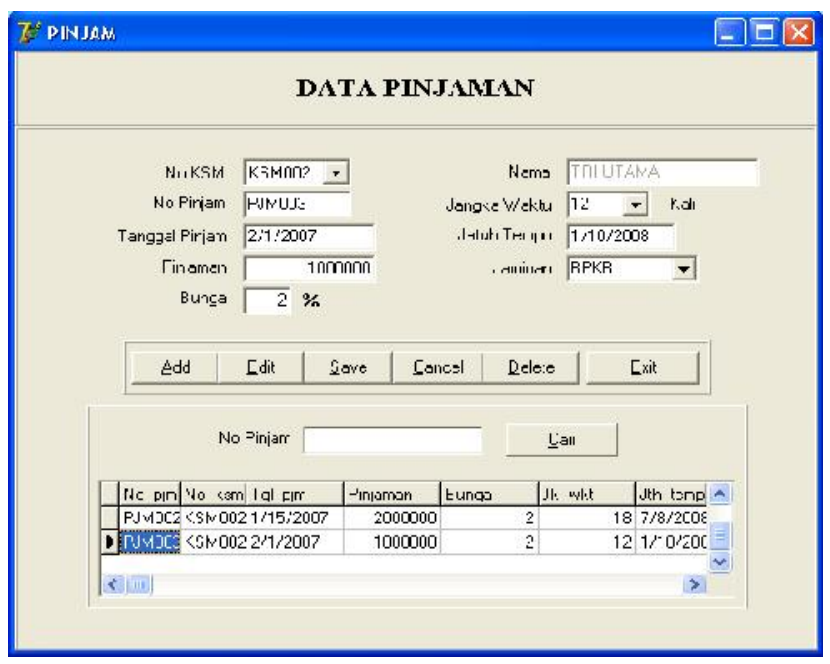

Gambar 4. Form pinjaman

Pada form pinjaman ini berisi informasi data pinjaman KSM yang terdiri dari No KSM, No. Pinjam, Tanggal pinjam, Jumlah pinjaman, Besar bunga, berapa jangka waktunya, waktu jatuh tempo otomatis serta jaminan agunan yang digunakan.

Tampilan form Simpanan ditunjukkan pada gambar 5 berikut ini.

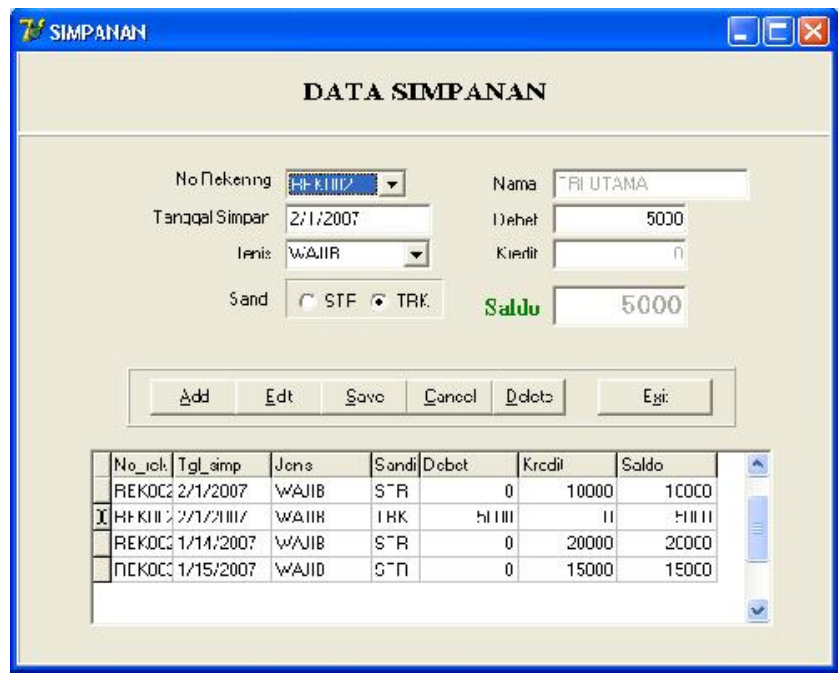

\section{Gambar 5. Form simpanan}

Pada form simpanan ini berisi informasi data simpanan KSM yang terdiri dari No rekening, Tanggal simpan, Jenis simpanan, kegiatan setor atau tarik simpanan, jumlah debit atau kredit serta saldo terakhir yang ditampilkan.

Tampilan form Angsuran ditunjukkan pada gambar 6.. 


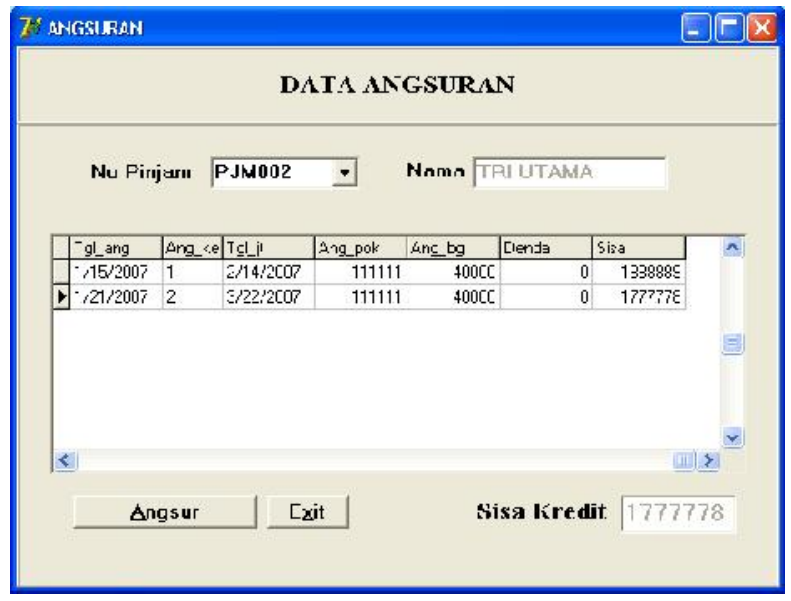

Gambar 6. Form angsuran

Pada form angsuran ini berisi informasi data angsuran KSM. Form angsuran ini dengan memasukkan no pinjam KSM kemudian diklik button angsur maka secara otomatis akan menambah data angsur pada bulan angsur sebesar jumlah pinjaman ditambah bunga dibagi dengan jangka waktu. Pada form angsuran ini juga menampilkan jumlah sisa kredit setelah dikurangi dengan angsuran pada bulan angsur.

\section{KESIMPULAN}

1. Sistem informasi simpan pinjam yang berbasis komputer dapat membantu bagian Unit Pengelola Keuangan dalam memproses data simpan pinjam menjadi lebih mudah, cepat dan tepat.

2. Sistem informasi simpan pinjam ini memuat informasi data KSM, data pinjaman, data simpanan dan data angsuran yang terhubung dengan data pinjaman.

3. Pembuatan Aplikasi simpan pinjam dapat dilakukan dengan menggunakan software visual borland delphi 7.0.

\section{DAFTAR PUSTAKA}

[1] Anonim, 2000, Pegangan Pelaku Kader Masyarakat, Proyek Penanggulangan Kemiskinan Direktorat Jendral Perumahan dan Pemukiman Departemen Permukiman dan Prasarana Wilayah, Jakarta

[2] Jogianto HM, 2005, Analisis dan Desain Sistem Informasi, Yogyakarta: Andi Offset.

[3] Hadiwijaya EC. RA, Rivai Wirasasmita, 1987, Analisis Kredit, Bandung: Pioner Jaya

[4] Suyatno Thomas, Chalik H. A, Dasar - Dasar Perkreditan, Edisi Keempat, Jakarta: PT Gramedia Pustaka Utama.

[5] Tuwarno dan Ramadhian, A.T., "Sistem Informasi Simpan Pinjam Koperasi Mitra Mandiri Jetak", Indonesian Jurnal on Computer Science Speed (IJCSS) 13 FTI UNSA, Vol 9 No 3 - Desember 2012 - ejournal.unsa.ac.id, ISSN : 1979-9330

[6] Atikah, H.R., dan Sukadi, "Sistem Informasi Simpan Pinjam Pada Koperasi Wanita Putri Harapan Desa Jatigunung Kecamatan Tulakan, Indonesian", Journal on Networking and Security (IJNS,) Volume 2 No 4 - Oktober 2013 ISSN: 2302-5700 